\section{LIBRI}

www.libridergi.org

Kitap Tanıtımı, Eleştiri ve Çeviri Dergisi

Journal of Book Notices, Reviews and Translations

Volume II (2016)

Y. YILMAZ, Anadolu'nun Gözyaşları: Yurtdışına Götürülmüş Tarihi Eserlerimiz. İstanbul 2015. Yem Yayınları, 312 sayfa (601 resim ile birlikte). ISBN: 9786054793471

\section{Ali Rıza BílgiN}

Libri: Kitap Tanıtımı, Eleştiri ve Çeviri Dergisi'nde bulunan içeriklerin tümü kullanıcılara açık, serbestçe/ücretsiz 'açık erişimli' bir dergidir. Kullanıılar, yayıncıdan ve yazar(lar)dan izin almaksızın, dergideki kitap tanııımı, eleştiri ve çevirileri tam metin olarak okuyabilir, indirebilir, dağıtabilir, çıktısını alabilir ve kaynak göstererek bağlantı verebilir.

Libri, uluslararası hakemli elektronik (online) bir dergi olup değerlendirme süreci biten kitap tanıtımı, eleştiri ve çeviriler derginin web sitesinde (www.libridergi.org) yıl boyunca ilgili sayının içinde (Volume II: Ocak-Aralık 2016) yayımlanır. Aralık ayı sonunda ilgili yıla ait sayı tamamlanır.

Dergide yayımlanan eserlerin sorumluluğu yazarlarına aittir.

Atıf Düzeni A. R. Bilgin, , Anadolu'nun Gözyaşları: Yurtdışına Götürülmüş Tarihi Eserlerimiz. Yazar: Y. Yılmaz. Libri II (2016) 413-416. DOI: 10.20480/lbr.2016029

Geliş Tarihi: 15.10.2016 | Kabul Tarihi: 25.11.2016 | Elektronik Yayın Tarihi: 20.12.2016

URL: http://dx.doi.org/10.20480/lbr.2016029

Editörya Phaselis Project

www.phaselis.org 


\title{
Y. YILMAZ, Anadolu'nun Gözyaşları: Yurtdışına Götürülmüş Tarihi Eserlerimiz. İstanbul 2015. Yem Yayınları, 312 sayfa (601 resim ile birlikte). \\ ISBN: 9786054793471
}

\begin{abstract}
Ali Rıza BílgiN*
Avrupa'da, eski eserlere duyulan ilginin temeli Rönesans'a kadar uzanmaktadır. Roma ve Hellen uygarlıklarına ait eserler bu ilginin merkezindedir. Bu bağlamda, 17. yüzyılda 'arkeolojik' olarak değerlendirilebilecek ilk çalışmalar gerçekleştirilmiştir. Illerleyen yüzyılda ise burjuva sınıfının kendi arasındaki rekabette eski eserlere sahip olmayı bir kazanç olarak görmesi, bu ilginin yavaş yavaş yağmaya dönüşmesine sebep olmuştur. 18. yüzyılın sonlarında, ulus kavramının etkisiyle, bu yağma yarışı bireysel olmaktan çıkmış ve milletlerarası hale gelmiştir. Bu noktada, tarih bilinci gelişmemiş olan Anadolu'da hâkim durumdaki Osmanlı İmparatorluğu bu yağma hareketinin hedefi olmuştur. Yaşar Yılmaz, kitabında 19. ve 20. yüzyıllarda Anadolu'dan kaçırılan ve şu anda Avrupa ve $A B D$ müzelerinde sergilenen eserlerin izini sürmektedir. Kitap bu konuda -yazarın tabiriyle- derli toplu yapılmış ilk çalışma özelliğini taşımaktadır. Eser, Kültür Varlıklarının Değerini Kavrama Süreci (16-38) ve Tarihi Eserlerimizin Bulunduğu Ülkeler ve Müzeler (42-292) olarak iki bölüme ayrılmaktadır. Kitap, ikinci bölüm sonundaki Öneriler (297-304) kısmı ile de son bulmaktadır.
\end{abstract}

Kültür Varlıklarının Değerini Kavrama Süreci (16-38) olarak başlıklandırılan ve de eserin girişi niteliğindeki bu bölümde, eski eserlere duyulan ilginin başlangıcı ve devamında eser kaçakçılığına dönüşen bu alakanın gelişim sürecine dair bilgiler verilmekte, sürecin nedenleri ve sonuçları çeşitli açılardan açıklanmaktadır;

"Eski eserler ilk olarak Batı Avrupa ülkeleri arasında popülarite kazanmıştır. Bu bağlamda ingiltere, Fransa ve Almanya gibi ülkelerde, bu eserlere ilgi duyan kişiler bazı cemiyetler kurmuşlardir. Bu cemiyetler tarafindan finanse edilen ekipler Italya, Yunanistan ve Anadolu'ya -başlardagezi amaçlı ve gördüklerini not almak üzere gönderilmişlerdir. Daha sonra bu geziler kaçakçılığa dönüşmeye başlayınca ilk italya ve daha sonra Yunanistan, ülkelerindeki eserleri koruma altına almak ve kaçırılmasını önlemek amacıyla yasal düzenlemeler gerçekleştirmişlerdir".

Bu değerlendirme ışığında yazar, Osmanlı kültüründe yeterince yer edinmemiş olan tarihi eserleri koruma bilincine vurguda bulunarak, eski eserleri korumaya yönelik çalışmaların geç başlamasını, çıkan kanunları ve bunların yetersiz kalmasını tarihî süreç ile birlikte değerlendirerek açıklamaktadır. Bölümün ilerleyen kısımlarında, Avrupa müzelerindeki bazı eserlerin künyelerinde, eserin getirildiği yer olarak Anadolu yerine Doğu Yunanistan yazılmasının sebepleri tartışılmaktadır. Bir sonraki alt başııta ise 19. yüzyıldan itibaren eski eserlerin savaş ganimeti

* MA., Ege Üniversitesi, Sosyal Bilimler Enstitüsü, Sanat Tarihi Anabilim Dalı, İzmir. bilgin420@gmail.com 
olarak değerlendirilmesi ve bunun Ortaçağa kadar uzanan örneklerine yer verilmektedir. Bölümün sonunda da 19. ve 20. yüzyıllarda, Anadolu'da çeşitli uluslarca tarihi eserlere yönelik yapılan araştırmalar ve bu araştırmalar sırasında kaçırılan eserlerin bir listesi sunulmaktadır.

Tarihi Eserlerimizin Bulunduğu Ülkeler ve Müzeler (42-297) başlıklı ikinci bölümde, eserlerin bulunduğu ülkeler ve müzeler alt başlıklar halinde sıralanmaktadır. Bu alt başlıklar da Almanya (42-98), Avusturya (98-116), Danimarka (116-124), Fransa (124-146), Hollanda (146-154), Ingiltere (154-220), Vatikan (220-224), Yunanistan (224-236) ve Amerika Birleşik Devletleri (236-297) olarak isimlendirilmektedir.

Almanya (42-98) alt başlığının girişinde, Osmanlı yönetiminin kendi toprakları içerisinde Almanlara tanıdığı imtiyazların tarihî süreci özetlenmektedir. İlerleyen kısımdaysa konunun detaylarına inilmekte, Almanların Anadolu'da yaptığı arkeolojik faaliyetlere yer verilmektedir. Bu bağlamda, Carl Humann'ın Pergamon'da yaptığı kazılar ve gün yüzüne çıkardığı eserleri yurt dışına çıkarışı kendi notları üzerinden açıklanarak nakledilmektedir. Daha sonrasında, Miletos ve Priene'den Almanya'ya götürülen arkeolojik buluntulara değinilmekte, akabinde Miletos'tan götürülen ve Berlin'de Pergamon Müzesi'nde sergilenmekte olan Agora Kapısı üzerine yorumda bulunulmaktadır. Ayrıca, Carl Humann'ın başında bulunduğu, Gaziantep Zincirli'de kurulmuş bir Hitit kenti olan Sam'al'da yapılan kazılar ve eserlerin götürülmesi sırasında yaşanan olaylar mercek altına alınırken, kültürel eserler konusunda sorumluluk bilincine sahip olduğu bilinen Osman Hamdi Bey'in eserlerin yurtdışına çıkarılmasına göz yumması da eleştirilmektedir. Alt başlığın sonunda Troia antik kentinin $\mathrm{H}$. Schliemann tarafından keşfi ve sonrasında bir defineci yöntemiyle yağmalanması anlatılmaktadır. Ayrıca, Troia'dan kaçırılan eserlerin Ikinci Dünya Savaşı ve sonrasında dünya müzelerine dağılışına da değinilmektedir. Son olarak, 66. ve 97. sayfalar arasında, araştırmacının tespitini yaptığı, Anadolu'dan kaçıılan ve Almanya'nın çeşitli müzelerinde sergilenen eserlerin fotoğrafları, görsele ait açıklamalarıyla birlikte sunulmaktadır.

Avusturya (98-116) isimli ikinci alt başlık, Avusturyalıların Ephesos'ta kazı yapmak üzere Osmanlı hükümetinden gerekli izni almalarıyla ilgili sürecin kısa bir değerlendirmesiyle başlamaktadır. Buna ek olarak, Ephesos antik kentinin tarihi ve önemi de vurgulanarak özetlenmektedir. Ayrıca, Avusturyalıların Otto Benndorf başkanlığındaki bir heyet ile Ephesos'ta kazılara başlamaları ve devamında gün yüzüne çıkardıkları arkeolojik buluntuları kendi ülkelerine nakletmeleri süreci değerlendirilmektedir. Bu eserler arasında bulunan Partlar Anıtı'nın önemine de dikkat çekilmektedir. Avusturyalıların Ephesos'taki faaliyetleri dışında, Myra (Demre) yakınındaki Gölbaşı'nda bulunan Trysa Anıtı'nın yurtdışına çıkarııması aşaması, O. Benndorf'un kendi yayınları üzerinden açıklamalar ile nakledilmektedir. Sayfa 108 ile 115 arasında, Avusturya müzelerinde sergilenen ve Anadolu'dan götürülmüş eserlerin fotoğrafları ilgili açıklamalarıyla birlikte yer almaktadır.

Danimarka (116-124) alt başlığında ise anlatı kısa tutulmaktadır. Yazar burada, Danimarka müzelerindeki eserlerin gerçekleştirilen kazılardan çok kaçakçılık faaliyetleriyle elde edildiğini belirtmektedir. Ayrıca, Anadolu'ya ait arkeolojik eserleri; sergilendikleri müzeler, tür ve dönemlerine göre gruplamaktadır. 118. ve 123. sayfalar arasında ise, Danimarka müzelerinde sergilenen bu arkeolojik eserlerin görsellerine, ilgili açıklamalarıyla birlikte yer verilmektedir.

Fransa (124-146) alt başlığının girişinde Fransızların, Osmanlı hükümeti nezdinde kazandıkları imtiyazları ne şekilde aldıkları anlatılmaktadır. Ayrıca, Fransızların tarihi eser kaçakçılığına 18. yüzyıl ortalarında başlamış olduklarına vurgu yapılmaktadır. Alt başlı̆ıı ilerleyen kısmında, 
Fransızlar adına keşiflerde ve araştırmalarda bulunan Charles Texier'in amaç dışı kaçakçılık faaliyetleri kendi notları üzerinden aktarılmaktadır. Akabinde, Texier'i takiben Fransa'ya tarihi eser kaçıran diğer kişilerin isimleri de zikredilmektedir. 135. ve 146. sayfalar arasındaysa, Fransa müzelerinde sergilenen ve Anadolu'dan götürülmüş arkeolojik buluntuların görsellerine ve ilgili açıklamalarına yer verilmektedir.

Hollanda (146-154) alt başlığında yazar, Hollanda müzelerinde sergilenen arkeolojik eserlerin genellikle uluslararası kaçakçılık aracılığıyla elde edildiğini belirtmektedir. Eserleri Hollanda'ya kaçıran kişi olarak, Hollandalı büyük bir aile olan van Lenneplerin, İzmir'e yerleşen bir koluna mensup Alfred Oscar van Lennep gösterilmektedir. Yazar, Oscar van Lennep'in kaçakçılıkla olan ilişiğini de tarihi belgeler özelinde açıklamaktadır. Alt başlığın sonunda, 148. ve 153. sayfalar arasında bu ülkede sergilenen eserlerin görselleri sunulmaktadır.

Ingiltere (154-220) alt başlı̆ıının başında, İngiltere müzelerindeki arkeolojik eserlerin buluntu yerlerine dikkat çekilerek, bu müzelerin -neredeyse tamamen- dünyanın farklı yerlerinden toplanan arkeolojik buluntular bir araya getirilerek oluşturulduğu vurgulanmaktadır. Akabinde, İngilizlerin kültür sömürgeciliğindeki faaliyetleri de eleştirel bir dille özetlenerek aktarılmaktadır. Bu doğrultuda, İngilizlerin Anadolu'ya olan ilgilerinin diğer Avrupalılardan çok daha önce, 17. yüzyılda, Arundel kontu tarafından tarihi eser toplamak üzere görevlendirilen bir antikacıyla başladığına değinilmektedir. Akabinde, ilerleyen yüzyıllarda birçok gezinin yapıldığı ve bu gezilere ait notların sonraki definecilere/kaçakçılara rehber niteliğinde yayımlandığı aktarılmaktadır. Bu minvalde, 19. yüzyılın ilk çeyreğinde Anadolu gezilerine başlamış olan Charles Fellows'un seyahatlerine, notları üzerinden açıklamalarla geniş̧̧e yer verilmektedir. Aynı doğrultuda, C. Fellows'un ilk ve ikinci Anadolu gezileri sırasında yaptığı keşiflere ve üçüncü seferi esnasında Ksanthos antik kentinden ele geçirdiği eserleri ülkesi İngiltere'ye taşımasına detaylı olarak yer verilmektedir. Takiben, Ephesos Artemis Tapınağı'nın taşınması sürecine geçiş yapılmadan önce, tapınağın tarihsel süreç içerisindeki akıbetiyle ilgili olarak özet bir bilgi sunulmaktadır. Devamında da tapınağı bulmak üzere başlatılan kazıların başlangııında, İngilizler adına çalışan John Turtle Wood'un kazılar esnasında ele geçirdiği arkeolojik buluntuları İngiltere'ye göndermesi ve tapınağın bulunduğu yeri keşfetmesinden bahsedilmektedir. Ayrıca, Bodrum kalesi surları üzerindeki Halikarnassos Mozalesi'ne ait kabartmaların, İngiliz büyükelçisi Stanford Cannig'in çabaları sonucu sökülerek İngiltere'ye nakledilmesi süreci, eserin tarihçesine dair bilgiler ile birlikte anlatılmaktadır. İngilizlerin Anadolu'daki faaliyetlerine dair son olarak, Gaziantep yakınlarında, Türkiye-Suriye sınır hattı üzerindeki Cerablus'ta bulunan ve bir Hitit kenti olan Karkamış'taki -ingiliz- kazılarından söz edilmektedir. Araştırmacı tarafından tespiti yapılan ve İngiltere'ye kaçırılarak Ingiliz müzelerinde sergilenmekte olan arkeolojik eserlerin görselleri ise, 182 ve 219. sayfalar arasında sunulmaktadır.

Vatikan (220-224) alt başlığında, Papalığın kendisini Roma İmparatorluğu'nun varisi görerek 1503 yııında Vatikan müzelerinin temelini atmasına değinilmektedir. Ayrıca, doğrudan kazılar düzenlenmediği için Vatikan müzelerindeki eserlerin dolaylı yollardan müzeye getirildiği belirtilmektedir. 222. ve 235. sayfalar arasında da Vatikan'da sergilenmekte olan, ancak Vatikan'da bulunmamış arkeolojik eserlerin görsellerine yer verilmektedir.

Amerika Birleşik Devletleri (236-297) olarak adlandırılan son alt başlıkta, Amerikan iç savaşının bitmesinin hemen ardından Amerikalıların da kültür sömürgeciliğine (sonradan) dâhil olduğu vurgulanmaktadır. Akabinde, Amerikan Arkeoloji Enstitüsü'nün, Assos ve Nippur antik kentle- 
rinde yaptıkları kazılardan bahsedilmektedir. Ayrıca, buralarda yaptıkları kazılarda çıkarılan eserleri ülkelerine götürebilmek amacıyla çeşitli politik oyunlar ile Osman Hamdi Bey'i memnun etmeye çalışmalarına genişçe yer verilmektedir. Son olarak, Sardeis'te gerçekleştirilen Amerikan kazılarına da değinilmektedir. Sayfa 246 ile 296 arasındaysa, Amerika Birleşik Devletleri'ndeki müzelerde sergilenen, ancak Anadolu'dan kaçırılmış olan arkeolojik eserlerin görselleri sunulmaktadır.

Öneriler (297-302) alt başlı̆ı ise kitabın sonucu niteliğindedir. Burada yazar, kültür varlıklarının kaçırılmasını önleyebilmek, hatta geri iadesini sağlayabilmek amacıyla iki başılı halinde öneriler getirmektedir. Bu bağlamda ilk olarak, eğitim alanında yapılacak olan düzenlemeler ile tarih bilinci daha sağlam nesiller yetiştirilmesi gerektiğini belirtirken, ikinci olarak ise kültür varlıkları kaçırıımış diğer ülkeler ile uluslararası ortakıklar geliştirilerek, kaçırılan eserlerin iadesi için adımlar atılması gerektiğini önemle vurgulamaktadır.

Anadolu'dan tarihî eser kaçırma, günümüzden yaklaşık iki yüzyı öncesinde başlayıp uzunca bir süre devam etmiştir. Bu, bilinen bir gerçek olmasına rağmen bu konu üzerinde fazla durulmamış ve ayrıntılar göz ardı edilmiştir. Eser, bu konuyu doğrudan ele alıyor olması bakımından oldukça önem arz etmektedir. Yazar tarafından eserin sadece bir giriş çalışması niteliği taşıdığı belirtilmiştir. Bu bağlamda kitapta kataloglanmış olan eserlerin sayısı göz önüne alındığında, Anadolu'dan götürülmüş ve diğer ülkelerin müzelerinde sergilenmekte olan eserlerin sayısı, tahmin edilenden çok daha fazla olmalıdır. Bir diğer üzücü gerçek ise bu kaçakçılığın bilim adı altında bilimsellikten çok uzak yöntem ve amaçlarla yapılmış olmasıdır. Defineci zihniyle iptidaî bir şekilde gerçekleştirilen çalışmalar neticesinde, tarihin bazı noktalarına açıklık getirebilecek olan arkeolojik buluntular gün ışığı göremeden telef olmuşlardır. Sonuç olarak, Yılmaz’ın bu eseri, uzun yıllardır görmezden gelinen önemli bir konuya dikkat çekmektedir. Yazarın da önsözünde belirttiği üzere gelecekte, bu kitap kaçırılmış olan bu eserler ile ilgili yapılacak olan her türlü çalışmada bir başlangıç noktası olarak kabul edilecektir. 